УДК 821.161.2-32.09:[81’276.6:641]

Ковпік C. I., доктор філологічних наук, професор кафедри української та світової літератур ДВНЗ «Криворізький державний педагогічний університет»

\title{
ГУСТАТИВНИЙ КОД ЗБІРКИ ОПОВІДАНЬ Н. ГУК «КНИГА ІСТОРІЙ ТА РЕЦЕПТІВ СМАЧНОГО НАСТРОЮ»
}

У статті з точки зору поетики густативів розкодовано сутність смислів $i$ надсмислів, котрі закладені у процесах приготування й подавання деяких страв, з метою 
створення приємного настрою, вирішення складних життєвих проблем, подолання родинних конфліктів тощзо.

Помічено, щцо Н. Гук використала практично всі прийоми передачі густативних якостей страв: від контекстуальних переліків та констатації до створення складних інтертекстуальних ситуаиій. А в кількох оповіданнях їй вдалося створити ще й надзвичайно ефектні художні моделі та образи, як проиесів приготування $i$ споживання страв, довершені художні образи прочесів, так $і$ способів харчування представників різних начіональностей. Відзначимо, що у більшості оповідань Н. Гук для позначення процесів колективного вживання їжі використовує лексему «трапеза» та дієслово «трапезувати». Письменниця пропонуе читачеві, напрочуд, багатофункціональні рецепти страв, більшість назв оповідань книги містять «глютонічні топоси». Н. Гук з допомогою художніх засобів спробувала передати багату палітру ароматів страв, котрі готують ї̈ героїні. А тому процес прочитання «Книги історій та рецептів смачного настрою» виконує одну із важливих функиій - збудження апетиту рецииієнта.

Ключові слова: густативний код, поетика густативів, художні образи та моделі прочесів приготування страв.

This article investigates in terms of gustatory poetics the essence of meanings and extrameanings, hidden in the process of cooking and serving some dishes, in order to create delicious moods, solve difficult life problems, overcome family conflicts etc.

The paper shows that $N$. Huk uses practically all the methods to transmit gustatory qualities of dishes strating from contextual lists and statements to creating complex intertextual situations. In several stories the author manages to make not only extremely spectacular artistic models and images of cooking processes and meal comsuming, but also the ways of nourishment special for the representatives of different nationalities. It should be noted that in most stories $N$. Huck uses the lexeme "meal" and the verb "to feast" to refer the processes of collective food consumption. The writer offers the reader, surprisingly, the multi-purpose recipes of dishes. Moreover it should be mentioned that most of the story tittles contain "glutonic topos". N. Huck tries to describe a rich palette of dish aromas prepared by her characters by means of impressive means and artistic devices. As a result, the process of reading "The Book of History and Recipes For Delicious Moods" performs one of the important functions such as the whetting of the recipient's appetite.

Key words: gustatory code, gustatory poetics, artistic images and models of cooking processes.

В статье с точки зрения поэтики густативов раскодирована сущность смыслов и надсмыслов, заложенных в процессах приготовления и подачи некоторых блюд, с иелью создания приятного настроения, решения сложных жизненных проблем, преодоление жизненных проблем.

Отмечено то, что Н.Гук использовала практически все приёмы передачи густативных качеств блюд: от контекстуальных перечислений и констатации до создания сложных интертекстуальных ситуаџий. А в нескольких рассказах ей удалось создать ёще чрезвычайно эффектные художественные модели и образы, как процессов приготовления еды, так и поедания блюд представителей различных национальностей. Отметим, что в большинстве рассказов Н. Гук для обозначения прочессов коллективного принятия пищи использует лексему «трапеза» и глагол «трапезничать». Писательница предлагает читателю на удивление многофункииональные рецепты блюд, большинство названий рассказов книги имеет в своем составе «глютонические топосы». Н. Гук с помощью художественных средств попыталась передать палитру ароматов блюд, которые готовят её героини. Вот поэтому процесс чтения «Книги историй и рецептов вкусного настроения» выполняет одну из важных функиий - возбуждение аппетита реципиента.

Ключевые слова: густативный код, поэтика густативов, художественные образы и модели проиессов приготовления блюд. 
У 2016 році у серії «Теплі історії» з’явилася книга Наталії Гук «Книга історій та рецептів смачного настрою». У «Передмові» до книги авторка зазначила, що «кухня - це зазвичай найтепліше місие в будинку...» [Гук 2016:9], де збирається уся родина, на кухні планується життя родини, вирішуються різноманітні проблеми, розповідаються веселі й сумні історії у процесі приготування та поїдання смачних домашніх страв. На нашу думку, Н. Гук дуже точно помітила значення і роль не тільки кімнати як кухні, а й чітко визначила іiі функціональні особливості - згуртовувати родину.

Книга складається із 23 історій, котрі за жанром можна визначити як оповідання, сюжет усіх оповідань обов'язково складається із низки подій, котрі так чи так пов’язані 3 дійством приготування якоїсь однієї страви. Тож спробуємо у статті розкодувати смисли і над смисли, котрі авторка вклала у ту чи іншу страву, оперуючи концепцією поетки густативів, представленої у нашій монографії «Поетика густативів (на матеріалі української прози XIX століття) (2014).

Серед назв історій є досить традиційні, наприклад, «Сирно-грибний суп для чоловіка», «Смажена картопля по-студентськи», «Крем на десерт», Полуничне варення». Проте, більшість назв історій містять «глютонічні топоси»: «Борщ 3 англійським присмаком», «Вечеря по-болгарськи», «Хачапурі по-криворізьки», «Хрущики для весілля», «Печиво латвійські чаклунки» тощо. Ще одну групу назв історій становлять ті, котрі позначають учасників або суб'єктів, які пов’язанні не тільки 3 приготуванням їжі, але в першу чергу iз процесом пригощання: «Рулька для празького зятя», «Бешбармак для друга», «Сирники для коханої» тощо.

Отже, назви історій вказують на якості страв, густативні лексеми виконують функції максимального збудження апетиту читача, а оригінальна подача назви страви зацікавлює й спонукає реципієнта до прочитання тексту твору. А ще назви історій породжують низку реакцій та рефлексій психофізіологічного порядку (від найпростішого збудження апетиту до 
непередбачуваних передчуттів, пов'язаних 3 багатьма життєво важливими подіями).

Так, перша історія «Сирно-грибний суп для чоловіка» містить вказівку на те, кому саме призначена страва, а також вказує на основні інгредієнти розповсюдженої в Україні першої гарячої страви під назвою «суп». Проте, запропонований рецепт супу у творі далеко не українській, а привезений чоловіком героїні твору із далекої Баварії. Дружина, відчувши захоплення чоловіка цією стравою, вирішила іï приготувати з тією метою, аби потішити смакові уподобання коханого. Жінка помітила, що коли їі чоловік Сгор згадував про цей суп, то у нього текли слинки, а це підкреслює гаму відтінків смаків, котрі залишились у підсвідомості чоловіка під час поїдання смачної страви. Тож функція цього супу була одна - «порадувати коханого смаколиками» [Гук 2016:12].

Оскільки героїня аналізованого оповідання сучасна молода жінка Оля, то й рецепт супу вона віднайшла у «всезнаючому Гуглі» [Гук 2016:12]. Н. Гук зазначає, що незважаючи на суворість рецептури, але Оля зробила усе по-своєму. Як відомо, це усталений принцип усіх господинь, адже кожна додає щось своє до чіткого рецептурного припису, тим самим змінює якісні особливості страви.

А далі авторка подає процес приготування страви, вказавши на низку кулінарних операцій, котрі варто виконати, щоб сирно-грибний суп був смачним. У цьому процесі привертають увагу густативні лексеми 3 пестливими суфіксами: «картопелька брусочками», «курячий бульйончик», «лавровий листочок» [Гук 2016:12].

Процес приготування супу містить вказівки на якість страви на кожному iз етапів іï приготування: «Попереду очікувало найцікавіше - звичайний суп перетворити на крем-суп. За порадою колежанки Оля натерла два плавлені сирки, відділила в чашку бульйону, розмішала ретельно з натертою масою, влила назад. Суп набув сірувато-коричневого відтінку. На смак був гарний, але не вериковици, як хотілося» [Гук 2016:13]. Прийом градації допоміг 
максимально описати якість супу: «...натерла щее один сирок, розчинила, скоштувала. Виявилося набагато кращуе. ...четвертий сирок почимчикував до супу. Колір зробився теплий, вериковий, насичений. “М-м-м-м... Оиуе вже спрвжня смакота!"” [Гук 2016:13].

Отже, опис процесу приготування супу виявився максимально охудожненим, а це допомагає реципієнту краще уявити зовнішню фактуру страви.

Авторка вказала на особливі функції аромату страви: «Грибний аромат так прив'язався до карпатських спогадів, щзо Оля захотіла $i$ обстановку зробити автентичною» [Гук 2016:13]. Н. Гук не забула зробити акцент й на тому, як саме варто подати сирно-грибний суп, довершивши художньогустатвиний образ страви: «На стіл лягла нова лляна скатертина, до неї приєднався рушник, щзо був куплений три дні тому «на згадку». Із комори на світ з'явилися старенькы полумиски, які пам'ятали щуе бабусю» [Гук 2016:13].

В оповіданні «Борщ 3 англійським присмаком» мова йтиме про традиційну страву для української кухні, котра належить до перших гарячих страв у раціоні харчування українців, тобто борщ. Цікавим є той факт, що страва ця готується напередодні виїзду до однієї із найвідоміших європейських країн - Англії. Н. Гук звертає увагу на те, що борщ вчиться готувати молода дівчина Оксана, котра незабаром поїде на стажування до Англії. Дівчина прагне познайомити нових друзів в Англії з українською кухнею.

I тільки з другого разу дівчина таки навчилася готувати смачний борщ, але він суттєво відрізнявся від бабусиного й маминого, що по суті, $\epsilon$ характерним явищем в кулінарній практиці. В Англії дівчина сама запропонувала родині, в якій вона жила приготувати дві страви української кухні - це борщ і вареники з вишнями. Борщ готували у цій родині пісний, бо вони вегетаріанці. Проте, Оксану турбувало те, що смак цього борщу буде трішки інший. Перші пахощі від борщу змусили родину англійців по черзі зазирати на кухню. 
Презентуючи цю страву, Н. Гук акцентувала увагу на процесі смакування страви, котра була маловідомою англійцям: «Усі інші представники великої родини спочатку звичайно, дуже обережно та з підозрою колупали ложками в тарілках, вишукуючи знайомі інгредієнти та дивуючись, що ие взагалі за страва: для супу - надто густа, для рагу - рідка, на салат зовсім не схожа» [Гук 2016:20]. У цьому описі є вказівки на інтенсивність смакових ознак страви, а густативні лексеми «густа», «рідка» актуалізують конкретне смакове значення указаної страви. Більше того, письменниця підкреслила важливий факт у споживані борщу іноземцями - вони віддали «шану смаку та “змісту”» [Гук 2016:20] цієї страви.

Отже, в оповіданні «Борщ 3 англійським присмаком» Н. Гук практично уникнула рецепторних приписів щодо процесу приготування борщу. Вона сфокусувала увагу читача на тому, які смакові відчуття викликає українська страва у представників інших націй.

Назва наступного оповідання «Рулька для празького зятя» містить вказівку на одну із частин свинячої туші, яка прилягає до колінного суглобу і вважається делікатесним м'ясом. Страва під назвою «Вепрове коліно» або «Рулька» - це традиційна страва чеської кухні, тож теща вирішила продемонструвати свої вміння готувати національні страви для чеського зятя. У переліку страв для чеського зятя Н. Гук використовує на позначення якості страви прикметник «свіженький», коли мова йде про рибну страву з коропа. Письменниця підкреслила й те, як старанно теща вибирала рецепт найсмачнішої рульки в Інтернеті, як декілька разів тренувалася, щоб виробити навички приготування цієї страви.

Привертає увагу й те, як візуалізувала Н. Гук, 3 допомогою густативних прикметників, готову страву: «Жінки побачили на столі духмяну, рум’яну рульку...» [Гук 2016:26]. А ще письменниця детально, як справжній гурман, презентувала харчосмакові якості вже готової страви: «...скоринка, м’якість, уміст солі $і$ приправ - усе здавалося неперевершеним» [Гук 2016:26]. 
3 допомогою прикметника «неперевершений» авторка розширила вже наявне семантично-семасіологічне поле густативу.

Отже, Н. Гук представила розгонуту, художньо-словесну модель процесу приготування рульки, адже авторка 3 етнографічно-рецепторною точністю говорить про всі етапи приготування страви, як про таку завершену систему жестів і рухів, котра сприймається як виключно старанна й відповідальна робота господині.

Виявом високої якості приготування рульки для чеського зятя видався сам процес і спосіб іï поїдання гостем: «Зате Карлові очі виблискували, а сам він тільки й прицмокував язиком» [Гук 2016:28].

Отже, в оповіданні «Рулька для празького зятя» авторка подала дієві описи приготування страви, котрі хоча й не належить до національної української кухні, проте на процесі їх приготування так чи так, але все ж таки позначилися харчосмакові уподобання української господині.

Назва наступного оповідання «Рибне кохання», на перший погляд, позбавлена будь-яких густативних характеристик. Проте, вислів «Найкраща риба - ковбаса» чітко вказує на те, що мова йтиме про рибну страву. Смакові якості риби, у будь-якому вигляді, до вподоби виявилися головному персонажу оповідання - Зої. Дівчина, як зазначила письменниця, мала «геніальний нюх на рибні страви» [Гук 2016:33], а коли бачила їх то аж «облизувалася». У даному разі лексема «облизувалася» указує на підвищену функцію рефлекторних дій дівчини, спричинених подразником їжі.

Ще смачнішими рибні страви виявилися під час відпочинку Зої та їі подруги на берегах Будацького лиману, адже саме там риба готувалася поособливому. Як виявилося, секрет смачної запеченої рибки полягав у тому, що вона готувалася на свіжому морському повітрі, а це, в свою чергу, максимально збуджувало апетит відпочиваючих.

Тож, в оповіданні «Рибне кохання» такі словосполучення, як: «запечена рибка», «свіже морське повітря» утворюють «глютонічні топоси», тобто 
лексеми на позначення таких якостей страв і харчів, які залежать від місця i умов харчування.

На думку В. Ніколенка, «...кухня будь-якої країни, нащіï - цуе частина ї̈ культурного багажу, своєрідне відображення історичного досвіду, окремих форм прояву масової свідомості, сочуільно-економічного стану тощзо» [Ніколенко 2015:337].

В оповіданні «Вечеря по-болгарськи» авторка створила густативні образи болгарської національної кухні, котрі виконали одну із важливих функцій інформативну. Так, національна страва болгар під назвою «чушки-бюрек» неабияк привабила головного персонажа твору - молоду дівчину Антоніну, яка під час відрядження до Болгарії вирішила познайомитися 3 місцевою кухнею. Як виявилося, за такою, геть не зрозумілою для українки, назвою приховувався звичайний болгарський перець фарширований сумішшю з бринзи, яєць і зелені.

А ось назва наступного оповідання «Смажена картопля по-студентськи» викликає спогади про один із найцікавіших періодів життя кожної людини, котра була студентом і жила в гуртожитку. Бо саме смажена картопля входить до «ТОП-5 студентських страв», котрі допомагають студентам вижити у гуртожитку. Чому українське студентство так обожнює цю страву ? Відповідь проста - вона смачна, проста в приготуванні й дешева. Ось і персонажі зазначеного вже оповідання студентки приготували картоплю по-студентськи. Приготовлена страва була духмяна, рум’яна «...3 ароматом цุибульки та часнику, ніжна така, ще розкришується під легким натиском виделки» [Гук 2016:46]. Цей густивний опис характеризує харчосмакові якості приготовленої страви і на рівні форми, і на рівні змісту. Н. Гук з допомогою прийому градації підкреслила те, як смакові якості смаженої 3 цибулею картоплі збуджують апетит: «Вікусі таки дістало сміливості скуштувати картоплю з изибулею та часником. Спочатку їла дуже повільно, узяла мізерну поризію. Потім - уже більшу» [Гук 2016:46].

Таким чином, письменниця 3 допомогою невеличкого, але досить вдало підібраного ряду якісно-оцінювальних прикметників, кількох виразних 
прийомів, епізодів, реакцій та рефлексій персонажів створила надзвичайно реалістичну й характеристичну картину способу харчування студентів.

У назві оповідання «Бешбармак для друга» фігурує лексема «бешбармак», значення якої для українського читача малозрозуміле або й невідоме. Ще важче читачеві уявити цю страву, допоки один із персонажів не перерахує необхідні інгредієнти для іï приготування: яловичина, курятина, яйця, борошно, цибуля. Та, власне, й цей перелік навряд чи допомагає сформувати уявлення про харчосмакові якості страви. Н. Гук дуже обережно через систему констатації та діалогів друзів розкриває специфічні особливості бешбармаку: «Данило чекав гостей. Стіл був накритий: печеня, деруни й навіть борщ - усе, щуо Данило вмів гарно готувати, він пропонував гостям.

- Ого ! - вигукнув Айгерим. - Ти впевнений, щзо бешбармак також хочеш готувати ?

- Звісна річ! Ви куштуватимете українські страви, я - казахські» [Гук 2016:51]. Отже, страва під назвою «бешбармак» належить до казахської національної кухні, яку готували колективно. Тобто, вказана страва виконує одну із важливих функцій їжі - об’єднувальну. Адже й сама назва страви перекладається як «п’ять пальців». А як відомо, «... колективне приймання їжі постає як окреме соиіальне дійство, у якому гастрономічні маркери інколи посилюють відчуття власної ідентичності й тим самим надають імпульси для об’єднання, солідаризащії соціальної групи, унаслідок чого часто-густо дозволяють проводити демаркаційну лінію у процесах віншування» [Гук 2016:47].

У процесі приготування цієї страви друзі обмінювалися інформацією про неї. Так, Айгерим повідомив, що бешбармак не можна однозначно зараховувати до кухні казахської, турецької, узбецької «або ще якоїсь...» [Гук 2016:52], адже це страва кочовиків, а до них належали представники різних народів. Проте, як виявилося із розповіді Айгерим, бешбармак у кожного із зазначених народів має суттєві відмінності щодо рецептурних приписів, харчосмакових якостей: «Киргизи замість ромбів із тіста виробляють тоненьку локиину. До бульйону 
додають моркву та селеру. Цибулевий соус називають «чик», а ми - «туздик». Узбецький рецеепт передбачає більщу кількість овочів... таджики додають томатну пасту» [Гук 2016:52-53].

Окрім процесу приготування страви, письменниця представила в оповіданні й «правильний спосіб» іiі поїдання, подавання на стіл, що не менш важливо для усвідомлення харчосмакових якостей бешбармаку: «Айгерим, послідовно викладав складові бешбармаку на велике блюдо, як того вимагає казахський звичай. Першим шаром - тісто. Розклав його ближче до країв тарелі. Усередину поклав иматки всіх сортів м'яса, включаючи порізані та підігріті кази. Поверх усього страву полив тудзиком, бульйон Марат розлив у глибокі піали...» [Гук 2016:53]. Як зазначають ресторатори, «дуже важливо не тільки правильно зробити бешбармак, але й бездоганно його подати» [Ревель 2004:231]. Спеціалісти цієї галузі знань виокремлюють три види подачі бешбармаку. В оповіданні Н. Гук презентовано один із видів, котрий має назву «класичний», адже саме така подача цієї страви, розкриває іiї дивовижний аромат. I дійсно, як зазначає письменниця, «Аромат стояв такий...» [Гук 2016:53].

Таким чином, в проаналізованому оповіданні «Бешбармак для друга» густативний образ страви під назвою «бешбармак» виконує такі функції: інформативну, об’єднувальну, гедоністичну, пізнавальну.

У збірці оповідань «Книга історій для смачного настрою» Н. Гук презентувала страву, котра не належить до національної кухні, але іiі смакові якості імпонують українців - це страва хачапурі. Глютонічний топос назви оповідання «Хачапурі по-криворізьки» вказує на спосіб приготування цієї страви, адже головний персонаж родом із Кривого Рогу. 3 допомогою прийому констатації авторка перераховує необхідні для приготування хачапурі види сиру: «Кисломолочний, м'який, делікатесний, гострий та сулугуні або бринза» [Гук 2016:59]. У вказаному переліку з допомогою густативних прикметників нормативного смаку Н. Гук розширила харчосмакове мікропіле страви, досягла очікуваного ефекту насичення смаку. Процес приготування хачапурі виконує 
об’єднувальну функцію, бо іï готують дід та онук. Так, під час приготування хачапурі дід інформує онука про сутність грузинських хачапурі та розкодовує зміст номенів «пури» (хліб) та «хачо» (розсипчастий сир). І ця розповідь діда про хачапурі не безпідставна, адже рецепт цієї страви у родинах мешканців гір передається з покоління у покоління. Назви решти видів хачапурі походять від назви місцевості, де їх виготовляють. Це такі глютонічні топоси: «імеретинські хачапурі», «мегрельські хачапурі», «хачапурі по-аджарські». 3 допомогою порівняння Н. Гук охудожнила хачапурі по-аджарські: «Вони - мов човники, 3 пухкими хлібними бортами, сиром і маслом (замість палуби) та схожим на прапор свіжим яєчком, щзо його повар вбиває у гарячий виріб перед тим, як віддати гостеві» [Гук 2016:60].

Як виявилося, особливістю хачапурі по-криворізьки $є$ форма i спосіб приготування, адже начинки у них кладеться у двічі більше, ніж тіста, а за формою вони прямокутні. Тобто, якість приготування, текстура тіста та його форма стали ще однією модифікацією цієї страви.

Отже, харчовий код аналізованого тексту оповідання починає сприйматися не лише як засіб характеристики самих персонажів, а й як вияв їхнього статусу та характеру їхніх міжособистісних стосунків. Складні якісні прикметники смаку (пікантний, кисломолочний), незважаючи на їхню малочисельність, виконали у тексті важливі смислові та емоційні функції.

Зворушливо й густативно вдалося Н. Гук розкрити функції млинців у долі різного віку жінок в оповіданні «Млинці до першого снігу». 3 особливою любов’ю авторка називає ці хлібобулочні вироби «сонячними запашними кругляками» [Гук 2016:67]. Письменниця акцентує увагу на тому, що головний персонаж твору Соня приготувала смачні млинці тому, що «з добрим настроєм узялася до справи» [Гук 2016:67]. Авторка вказала й на текстуру тіста: «..вдалося гарне, без грудочок» [Гук 2016:67], а це один із показників високої якості страви. Особливо художньо 3 допомогою елементарних якісних прикметників описує Н. Гук перший млинець: «гарячий, запашний, підсмажений, щзойно з пательні» [Гук 2016:67]. Ознаки позитивної оцінки 
смакової якості млинців письменниця досягла шляхом морфологічної деривації якісних прикметників: «рівнесенькі, круглесенькі» [Гук 2016:67]. Така художньо-візуальна характеристика не тільки інформує про результати випікання млинців, а й максимально збуджує апетит реципієнта, активізує його ольфатично-сапористичні відчуття.

Кулінарним чудом виявилася форма сирників у наступному оповіданні «Сирники для коханої», котрі були зроблені у формі сердечок. Тут авторка підкреслила те, що інколи подача звичайної страви може перетворити іiі на кулінарний шедевр або кулінарне чудо. Сирникові сердечка виконали декілька функцій: гедоністичну, естетичну, об’єднувальну.

Не менш густативно наснаженим виявилося оповідання «Хрущики до весілля», тобто назва вказує на те, що мова йтиме про обрядову страву. У звичний процес святкування дня народження працівниці однієї із фірм, Н. Гук дуже вдало вмонтувала знакову деталь - страву «хрущики», котра визначила долю дівчини Ярини. Хрущики, котрих вона напекла для колег на святкування свого дня народження виявилися пухкенькими, посипаними білосніжною пудрою. I саме смак хрущиків змусив одного із колег на ім'я Петро «перенестися на два десятки років» [Гук 2016:76] назад і пригадати свої ще дитячі відчуття від поїдання цієї страви у бабусиному будинку. Адже відомо, що смакові уподобання дитинства та юності досить стійкі, бо саме смакові рецептори дитини здатні зафіксувати найбажаніші смаки. А ще до смакової пам’ятті додалися спогади про історію 3 хрущиками, котру розповідала бабуся. Бабасуя хрущиками називала вергуни, проте вони дещо відрізнялися від хрущиків Ярини. Вергуни були «... не тонесенькі, a пухкі, великі...» [Гук 2016:77]. 3 допомогою якісних прикметників Н. Гук передала текстуру страви, а завдяки сполучнику протиставлення «а» пояснила відмінність хрущиків від вергунів. Власне ця борошняна страва змусила Петра зовсім по-іншому подивитися на Ярину. Харчосмакові спогади дитинства, уміння дівчини готувати звичні домашні страви стали основою для зародження більш глибокого почуття - любові. 
Секрети м’якого тіста для вареників Н. Гук розкриває й у наступному оповіданні під дуже категоричною назвою «Свекруха, вареники і всі-всі-всі». Саме у цьому оповіданні письменниця зробила акцент на низці операцій, що пов’язані 3 технологією приготування вареників: «...взялися в чотири руки нарізати тісто на шайбочки, розкачувати, начиняти» [Гук 2016:82]. А далі 3 допомогою метафоричного порівняння Н. Гук охудожнила такий звичний процес ліплення вареників: «Люся дуже красиво заліплювала, немов мереживо плила» [Гук 2016:83]. Тут авторка використала тільки один «інструментатив», тобто лексему на позначення тих засобів, 3 допомогою яких здійснюються процеси приготування вареників: «спеціiальна сітка» [Гук 2016:83]. Особливість технології приготування вареників у цьому оповіданні полягала у тому, що готові вареники складала господиня не в каструлю, не в миску, а виключно на рушник, адже «вареники так не злипаються $i$ зберігаються довще смачними та свіжими» [Гук 2016:83].

Н. Гук серед безлічі цікавих рецептів страв, пропонує й такі, котрі покращують емоційний стан людини і навіть лікують від апатії. Як, наприклад, шоколадний кекс. В однойменному оповіданні авторка ще раз підкреслює те, що українські господині дуже винахідливі. Процес приготування шоколадного кексу виявився також максимально охудожненим. Так, письменниця 3 допомогою порівнянь створила повноцінний образ майбутньої страви: «Молоко й масло приєдналося до темної, наче безодня, і солодкої, ніби мрї, сумімі» [Гук 2016:89], «кекс був темно-коричневий та смачний, мов спокуса» [Гук 2016:89].

I якщо персонажами усіх попередньо проаналізованих оповідань були люди, які не пов’язані особливо зі сферою гастрономіі, то в оповіданні $з$ досить привабливою назвою «Печиво латвійської чаклунки» персонажі є професійними рестораторами, а події у творі відбуваються безпосередньо у самому ресторані. 3 допомогою детальних описів інтер'єру ресторану письменниця ввела читача у гастрономічний світ персонажів. Н. Гук акцентує увагу на функціональних особливостях спогадів, котрі пов’язані зі смаком. Власниця ресторану 
пригадала незабутній смак печива, котра вона скоштувала дуже давно в Ризі. Жінка зі знанням усіх тонкощів кулінарного дійства відтворила дивовижний смак латвійського печива під назвою «Піпаркукас» (перчене печиво): «По-перше, дуже гарне: маленькі фігурки різної форми та розмальовані кольоровою поливою. По-друге, таке духмяне, запашне, з насиченим пряним смаком, щзо торкався, усіх рецепторів тіла» [Гук 2016:95-96]. У цьому описі $є$ вказівка на форму й зміст страви, а ще 3 допомогою гіперболи Н. Гук максимально візуалізувала харчосмакові особливості печива.

Пестливо й ніжно Н. Гук називає деякі страви, котрі створюють приємний настрій, змушують поринути у світ дитинства: «Картопелька, як у дитинстві». У цьому оповідання солодке тістечко «Картопелька» виконує функцію реанімації дорослої пам’яті про дитячі смаки й уподобання. Смак страви, котру діти приготували власноруч у дитинстві запам'ятовується на все життя і саме цей смак є приємним нагадуванням про ті часи, коли все було добре. Дорослі жінки через багато років згадали невдале приготування тістечка «Картопелька», але попри це, згадує одна, «...̈̈л та щ̧е прищммокували!» [Гук 2016:112], бо найкращим було те у цьому рецепті, що подружки його зробили разом. Тобто, їжа як ніякий інший процес в житті людини виконує одну із позитивних функцій - об’єднує людей.

Наступна назва оповідання також вказує на об’єднувальні функції їжі та процесів iii приготування - «Родинний рулет із маком». Саме рулет 3 маком виконує у цьому оповіданні функцію примирення членів родини, котрі в результаті дрібної побутової сварки внесли в родину неспокій. Процес приготування тіста та начинки детально розкриває усі тонкощі смачного рулету 3 маком: «Тісто має бути м'якеньке, еластичне... Що ніжніше виходить mісто, то пухкіші пиріжки» [Гук 2016:116]. В описах є вказівки на текстуру тіста, рівень консистенції рідини, якість макової начинки: «...усі зернятка розкришуються, випускають сік, ретельно перемішуються 3 цукром» [Гук 2016:115], а також названі гастрономічні інструментативи: м'ясорубка, деко. 
Н. Гук постійно акцентує увагу на тому, що винахідливі українські домогосподарки можуть із невеликої кількості залишків продуктів приготувати святково-родинну страву. Як от, наприклад, в оповіданні «Шовковичні мафіни», де інгредієнти страв, як об’єкти дії, максимально оживленні: «...Ірина запросила до столу всі необхідні продукти: борошно, иукор, лимон, яйця» [Гук 2016:124]. У цьому інформативному описі привертає увагу дієслово «запросила», котре знаходиться в сильній позиції до іменників, що вказують на назви продуктів. Окрім цього, таке словосполучення «темний, густий кисіль» свідчать про насиченість смаку вказаної страви i про те, що iї готувала справжня майстриня.

На рівень якості приготовленої страви в аналізованому оповіданні вказує й таке підрядне речення якісно-порівняльного типу: «...батько з изікавістю дослідника куитував темний $i$ густий, наче саме нічне небо, кисіль» [Гук 2016:125].

У цьому оповіданні шовковичні мафіни та шовковичний кисіль виконують інформативну функцію, адже домогосподарка розповіла своїм дітям про лікувальні функції тутового дерева, чим значно урізноманітнила процес поїдання родиною страв 3 цієї ягоди.

У сюжет наступного оповідання Н. Гук оригінально вмонтувала рецепт страви «Крем на десерт», котру жінка на ім'я Галина удосконалювала усе своє життя. Відповідно до вікових здібностей Галини, іiі матуся 3 кожним роком ускладнювала алгоритм приготування улюбленого родинного десерту: «У десять рочків Галя тільки допомагала матусі - колотила желатин, м'яла щуосили на дощциі качалкою горіхи, ложками вимірювала пудру та какао. У чотирнадиять самостійно почала виробляти десерт, заздалегідь готуючи компоненти в різних мисочках на столі, щуоби не відволікатися в процесі збивання» [Гук 2016:129]. I на цьому процес удосконалення приготування десерту не зупинився. Бо вже у двадцять років вона виявила справжній інтерес до історії появи в родинні фірмової страви, про яку їй розповіла мама. Рецепт «Крему на десерт» - це витвір, котрий сягав часів радянської кулінарії, а 
поширювали його колеги 3 маминої роботи 3 уст в уста. У двадцять п’ять Галина переакцентувала увагу на те, в чому і як подавати улюблений десерт. Адже відомо, що поряд із приготуванням якісних страв посуд має дуже важливе естетичне значення, а це, в свою чергу, підсилює стимулюючу функцію страви: «Якщуо робити смакоту просто для себе та коханого, то можна використовувати пузаті великі склянки для компотів, одну пориію з їв - $i$ півдня ситий. Якщуо для гостей і хочеться подати красиво - то «мартинки» або коньячні бокали невеличкого розміру. Але найкращий посуд для крему - иче креманки під морозиво» [Гук 2016:130]. У цьому описі акцент робиться на тому, що в українців існувала традиція буденного й повсякденного посуду (про це ми вели розмову у монографії «Поетика густативів на матеріалі української прози XIX», 2014) й святкового, тобто посуд для себе і для гостей. I вже зовсім по-іншому ставиться Галина до свого улюбленого десерту, коли їй виповнюється тридцять років. Вона абсолютно впевнена у якості приготовленої страви, їй важливо, щоб іiі близькі та рідні отримали гастрономічне задоволення від процесу поїдання їі фірмового десерту. Тобто, Н. Гук представила еволюцію психоемоційних станів жінки у різні вікові періоди, котрі розкривають механізм життєвих навичок, що пов’язані з процесом приготування страв.

У книзі «Історій та рецептів смачного настрою» Н. Гук виявила високий ступінь поваги до страв i процесів їх приготування та споживання, продемонструвала ступінь вираженості свого та персонажного гурманства. А це, в свою чергу, свідчить про вміння митця формувати у свідомості реципієнта культуру харчування й елементи гурманства.

Більшість оповідань «Книги історій та рецептів смачного настрою» страви традиційно, як це й годиться, готують жінки, але в оповіданні «Домашня “Фанта”» письменниця відійшла від традиційного зображення жінки у ролі кулінарного гуру, віддавши це право чоловікові. Розповідаючи наступну смачну історію, Н. Гук акцентує увагу на записній книжці чоловіка, до якої він «старанно збирав із настінних відривних календарів та періодики рецепти» [Гук 2016:134]. Процес приготування фанти, як виявилося, навіть вплинув на 
покращення стану здоров’я вже немолодого чоловіка. Смачний та вітамінізований напій призначався для вагітної невістки, а тому свекор ретельно виконував усі покрокові кулінарні операції. Н. Гук подає процесуальний розлогий опис приготування домашнього напою, не вдаючись, як у попередніх оповіданнях, до охудожнення гастрономічних операцій. Напій справив на вагітну невістку неабияке враження, адже жінка не тільки втамувала спрагу, а й отримала густативне задоволення від напою, до складу якого входили такі поживні інгредієнти: свіжа морква, апельсин, лимон. Отже, вітамінній напій виконує в проаналізованому оповіданні оздоровчу функцію.

Багатофункціональне значення має рецепт наступної страви, котрий Н. Гук презентувала в оповіданні «Кава літературна». Основна подія твору - це піст, котрий для головного персонажу твору Соломії не просто обмеження в їжі, але й можливість духовного очищення. Як відомо, під час дотримання посту існує низка страв і продуктів, котрі заборонені. Соломія, як злісна кавоманка, вирішила проявити стриманість до свого улюбленого напою - кави. Піст для дівчини виявився своєрідним порятунком, адже вона відчувала, що кількість нею випитої кави шкідливо позначаються на стані іï здоров’я. Дівчина дуже виважено й грамотно підійшла до пошуку альтернативних напоїв. I таким виявився напій із карпатського цикорію, котрий «...y десять разів корисніший за каву» [Гук 2016:138].

Тож, Н. Гук використала практично всі прийоми передачі густативних якостей страв: від контекстуальних переліків та констатацій до створення складних інтертекстуальних ситуацій. А в кількох оповіданнях їй вдалося сконструювати ще й надзвичайно ефектні художні моделі та образи як процесів приготування i споживання страв, так i способів харчування представників різних національностей.

\section{БІБЛІОГРАФІЯ}

Гук 2016 - Гук Н. Книга історій та рецептів смачного настрою / Н. Гук. К. : Брайт Стар Паблішинг, 2016. - 160 с. 
Ковпік 2014 - Ковпік С. I. Поетика густативів (на матеріалі української прози XIX століття) : монографія / С. Ковпік. - К. : Інтерсервіс, 2014. - 168 с.

Ніколенко 2015 - Ніколенко В. Гастрономічні детермінанти суспільного життя: соціологічний вимір : дисерт. на здобуття науковго ступення доктора соціологічних наук : 22.00.01 - теорія та історія соціології / В. В. Ніколенко. Дніпропетровськ, 2015. - 663 с.

Ревель 2004 - Ревель Ж. Ф. Кухня и культура: литературная история гастрономических вкусов от античности до наших дней / Ж. Ф. Ревель ; [пер. с фр. А. Лушанова]. - Екатеринбург : У-Фактория, 2004. - 336 с. 